\title{
Małgorzata Świder
}

https://orcid.org/0000-0002-4354-3641

Uniwersytet Pedagogiczny im. Komisji Edukacji Narodowej w Krakowie

\section{Zachodnioniemiecka dyplomacja o zagrożeniu radziecką interwencją zbrojną w Polsce - jesień $1980 \mathrm{r}$.}

Zarys treści: RFN była żywotnie zainteresowana wydarzeniami w Polsce, a przede wszystkim groźbą interwencji ZSRR, która mogła poważnie skomplikować relacje RFN-NRD. W oparciu o niemieckie materiały archiwalne podjęto próbę odpowiedzi na trzy zasadnicze pytania: czy rząd RFN liczył się jesienią 1980 r. z interwencją ZSRR w Polsce? Jakie warunki musiały być spełnione, aby ZSRR zdecydował się na działania siłowe? Czy w ocenach RFN sytuacja w Polsce wykazywała podobieństwa do sytuacji w Czechosłowacji w 1968 r.? Odpowiedzi na te pytania pozwolą zrozumieć zarówno działania podejmowane przez Bonn wobec Polski i całego bloku wschodniego, jak i prezentowane przez polityków RFN postawy.

Outline of content: The Federal Republic of Germany was vitally interested in the events occurring in Poland and, above all, in the threat of Soviet intervention, which could seriously complicate the FRG-GDR relations. The author attempted to answer three fundamental questions based on German archival materials: Did the German government count on the USSR's intervention in Poland in the autumn of 1980? What conditions had to be fulfilled for the USSR to decide on forceful action? Did the German assessment of the situation in Poland show similarities to the situation in Czechoslovakia in 1968? Answering these questions will make it possible for us to understand Bonn's actions towards Poland and the entire Eastern Bloc and the attitudes presented by German politicians.

Słowa kluczowe: protesty społeczne w Polsce, interwencja radziecka, Republika Federalna Niemiec, NATO, Niemiecka Republika Demokratyczna, konsultacje międzynarodowe

Keywords: social protests in Poland, Soviet intervention, Federal Republic of Germany, NATO, German Democratic Republic, international consultations 
Radziecka strategia wobec protestującej Polski, a przede wszystkim pytanie: „Wejdą, nie wejdą?" były od lata 1980 r. przedmiotem powszechnych rozważań. Do dnia dzisiejszego kwestia ówczesnego zagrożenia Polski radziecką interwencją stanowi nieustannie temat badań i dyskursu naukowego ${ }^{1}$, a także polemik prasowych. Pomimo że opublikowano już wiele dokumentów i opracowań, wciąż odczuwany jest niedosyt $\mathrm{w}$ interpretacji zaistniałych - lub też niezaistniałych - faktów. Dla zrozumienia ówczesnej polityki, działań rządów i opinii publicznych znaczenie mają materiały źródłowe, które stają się dostępne dla badaczy. W naszym przypadku dotyczy to materiałów proweniencji zachodnioniemieckiej. Republika Federalna Niemiec widziała w napięciach społecznych artykułowanych od lata 1980 r. przede wszystkim zagrożenie dla relacji niemiecko-niemieckich (RFN-NRD $)^{2}$, stąd też przyglądano się w Bonn $\mathrm{z}$ dużym zainteresowaniem Polsce, zwracając uwagę na możliwe skutki napięć wokół Solidarności zarówno dla RFN, jak i dla NRD. Analizowano sytuację polityczną i potencjalne zagrożenie radziecką interwencją $\mathrm{w}$ Polsce, korzystając m.in. $\mathrm{z}$ relacji $\mathrm{z}$ tajnych rozmów i ustaleń dyplomatycznych, podjętych podczas spotkań z partnerami z Zachodu (zwłaszcza w ramach NATO) i ze Wschodu (głównie w Moskwie i Warszawie), a także z raportów Federalnej Służby Wywiadowczej (BND - Bundesnachrichtendienst), do której zadań należało informacyjne wspieranie rządu w podejmowaniu decyzji politycznych. Dla jakości pozyskanych informacji znaczenie miały m.in. rozeznanie dyplomatów na moskiewskiej scenie politycznej i ich bardzo dobre relacje z politykami radzieckimi. Politycznej interpretacji zebranych materiałów dokonywano w Urzędzie Kanclerskim, gdzie w małym gronie rozmawiano, analizowano i podejmowano decyzje o strategicznym znaczeniu dla RFN.

Dzięki odtajnieniu i opublikowaniu szeregu dokumentów z Archiwum Politycznego Ministerstwa Spraw Zagranicznych RFN, a także części innych źródeł archiwalnych i objęciu ich interpretacją naukową, można było pokusić się

${ }^{1}$ Literatura polska na temat groźby interwencji radzieckiej w Polsce, a także dotycząca wprowadzenia stanu wojennego jest bardzo bogata, tutaj przykładowo: R. Łatka, Prymas Stefan Wyszyński wobec zagrożenia interwencja sowiecką i konsekwencje jego poglądów (1980-1981), „Studia z Dziejów Rosji i Europy Środkowo-Wschodniej” 53 (2018), z. 1, s. 145-164; M. Żukowski, Stan wojenny. Analizy, hipotezy, komentarze, Koszalin 2012; A. Paczkowski, Moskwa a „kryzys polski” 1980-1982, w: Białe plamy - czarne plamy. Sprawy trudne w relacjach polsko-rosyjskich (1918-2008), red. A. Rotfeld, A.W. Torkunow, Warszawa 2010, s. 715-728; A. Paczkowski, Droga do „mniejszego zła”. Strategia i taktyka obozu władzy lipiec 1980 - styczeń 1982, Kraków 2002; W. Jaruzelski Różnić się mądrze. Jak doszło do stanu wojennego, Warszawa 2000; Przed i po 13 grudnia. Państwa bloku wschodniego wobec kryzysu w PRL 1980-1982, t. 1: Sierpień 1980 marzec 1981, wybór, wstęp i oprac. Ł. Kamiński, Warszawa 2006. Na szczególne wyróżnienie zasługuje obszerna praca zbiorowa pod redakcją Pawła Jaworskiego i Łukasza Kamińskiego, Świat wobec „Solidarności” 1980-1989, Warszawa 2013, dająca przegląd strategii wielu państw wobec wydarzeń w Polsce w dekadzie lat osiemdziesiątych XX w.

2 Szczegółowo o tej zależności zob. M. Świder, Stanowisko Socjaldemokratycznej Partii Niemiec wobec Polski w latach 1980-1989, Opole 2015. 
o zbadanie zachodnioniemieckich analiz i opinii na temat prawdopodobieństwa interwencji ZSRR w Polsce. Analizie poddano dokumenty z zasobów Archiwum Politycznego Ministerstwa Spraw Zagranicznych RFN, edytowane w latach 20112012 (Akten zur Auswärtigen Politik der Bundesrepublik Deutschland), a także materiały archiwalne wytworzone przez BND i obecnie zdeponowane w Archiwum Federalnym w Koblencji (BAK). Analizy źródeł dopełniają teksty naukowe, które ukazały się po $1990 \mathrm{r}$.

W oparciu o uzyskane wyniki podjęto próbę odpowiedzi na trzy zasadnicze pytania: czy rząd RFN liczył się w 1980 r. z interwencją ZSRR w Polsce? Jakie warunki musiały być spełnione, aby ZSRR zdecydował się na działania siłowe? Czy sytuacja w Polsce z jesieni 1980 wykazywała podobieństwa do sytuacji w Czechosłowacji w przeddzień interwencji wojsk Układu Warszawskiego w 1968 r.? Odpowiedzi na te pytania pozwolą wyjaśnić podejmowane przez Bonn działania wobec Polski i całego bloku wschodniego, zrozumieć postawy polityków RFN wobec Warszawy, a także uzupełnić obraz międzynarodowych reakcji na polski kryzys początku lat osiemdziesiątych XX w.

Od lata 1980 r. napływały do Bonn analizy i relacje odnoszące się zarówno do ówczesnej sytuacji w Polsce, jak i możliwej strategii ZSRR wobec wydarzeń nad Wisłą. Przykładowo 2 września 1980 r. ambasador RFN w Warszawie Georg Negwer przesłał do Bonn analizę zdarzeń w Polsce, określając ich rozwój jako anormalny $\mathrm{w}$ odniesieniu do rozwoju sytuacji $\mathrm{w}$ państwach socjalistycznych ${ }^{3}$ i rewolucyjny w sensie leninowskim ${ }^{4}$. Równocześnie zwracał uwagę, że sprawy Polski stały się przedmiotem wzmożonej obserwacji i pogłębionej analizy ZSRR i państw bloku wschodniego, które nastąpiły po porozumieniu się rządu ze strajkującymi ${ }^{5}$. Sukcesy organizacyjne strajkujących robotników wpłynęły najprawdopodobniej na sposób postrzegania wydarzeń w Polsce. Obawiano się, że na państwa bloku wschodniego „rozleje się” atmosfera nieposłuszeństwa czy wręcz strajków ${ }^{6}$, o czym mówił 23 września 1980 r. minister spraw zagranicznych PRL Józef

3 Akten zur Auswärtigen Politik der Bundesrepublik Deutschland 1980 (dalej: AAPD 1980), München 2011, dok. 256, Botschafter Negwer, Warschau, an das Auswärtige Amt, 2. September 1980, s. 1341.

${ }^{4}$ W tym wypadku chodziło o stosunek Moskwy do Solidarności. Jak pisze Anthony Kelp-Welch, towarzysze moskiewscy kwestionowali pojęcie „wolnego związku zawodowego” (w nazwie był „Niezależny”, ale prawdopodobnie traktowali niezależność i wolność jako synonimy) i „zadawali pytanie: «wolnym od kogo albo czego?». Lenin uczył, że «tak zwana „neutralność” związków zawodowych» to zakłamany pozór”. W oczach Moskwy Solidarność była niedopuszczalnym odstępstwem od leninowskiej ortodoksji. A. Kemp-Welch, Sowieckie reakcje na NSZZ „Solidarność” w latach 1980-1989, w: Świat wobec „Solidarności”..., s. 64.

5 AAPD 1980, dok. 256. Więcej na temat stosunku państw socjalistycznych do Polski w tamtym czasie zob. Świat wobec „Solidarności”..., passim.

${ }^{6} \mathrm{~W}$ połowie września $1980 \mathrm{r}$. wybuchły strajki kolejarzy z Deutsche Reichsbahn z Berlina Zachodniego, którzy od $1945 \mathrm{r}$. formalnie byli pracownikami wschodnioniemieckimi. We wrześniu $1980 \mathrm{r}$. doszło do eskalacji żądań płacowych i socjalnych oraz strajku okupacyjnego na stacji przeładunkowej Berlin Zoologischer Garten. Wschodnioniemiecka milicja kolejowa i działacze Sozialistische 
Czyrek na spotkaniu z ministrem spraw zagranicznych RFN Hansem-Dietrichem Genscherem. Czyrek wskazał na polską świadomość konsekwencji takich wydarzeń dla Europy Środkowej, jednocześnie wyrażając zaniepokojenie wrześniowymi strajkami w Berlinie Zachodnim, które mogły być interpretowane jako przejaw szeroko zakrojonej akcji skierowanej przeciwko status quo w Europie Środkowej ${ }^{7}$. Z tymi obawami korespondowały merytorycznie inne analizy, w tym również nadchodzące z BND ${ }^{8}$, w których podkreślano wybuchowy charakter protestów, a także ich antyradziecki wydźwięk, co mogło w przyszłości być podstawą do eskalacji napięć w Polsce, jak również w całym bloku wschodnim ${ }^{9}$. O wrażliwości radzieckiej na wypowiedzi działaczy Solidarności czy opozycji świadczyć mogą działania podjęte wobec Petera Rugego. We wrześniu 1980 r., na życzenie ZSRR, cofnięto temu korespondentowi stacji telewizyjnej ZDF akredytację dziennikarską. Pretekstem był wywiad przeprowadzony $\mathrm{z}$ Leszkiem Moczulskim, w którym znalazły się postulaty „wyzwolenia Polski z obozu socjalistycznego" i zlikwidowania dyktatury komunistycznej ${ }^{10}$.

Sytuacja w Polsce była bardzo dynamiczna i stwarzała wiele potencjalnych zagrożeń i napięć międzynarodowych, o czym pisał 19 września $1980 \mathrm{r}$. Ministerialdirektor Klaus Blech (kierownik Wydziału Politycznego w bońskim Ministerstwie Spraw Zagranicznych [MSZ]), relacjonując z Nowego Jorku posiedzenie Stałych Reprezentantów Rady Północnoatlantyckiej w tzw. małym kręgu (Francja, RFN, Wielka Brytania, USA). Podstawą jego oceny sytuacji była amerykańska informacja o ruchu wojsk przy granicy polsko-radzieckiej. Najprawdopodobniej wiązał się on z corocznymi manewrami, ale równie dobrze prowadzone ćwiczenia mogły służyć utrzymaniu gotowości bojowej na wypadek interwencji w Polsce ${ }^{11}$. Wzmocnieniem niepokojących opinii była informacja przedstawiciela USA z Komitetu Wojskowego NATO, który 22 września 1980 r. powiadomił stałych reprezentantów z „małego kręgu” o wysokim stopniu mobilizacji wojsk radzieckich na terytorium NRD i zachodnich obszarach ZSRR. W krótkim czasie 10 dywizji mogło być aktywnych na terytorium Polski. Bezpośrednich dowodów na przygotowania do interwencji zbrojnej jednak nie zanotowano ${ }^{12}$.

Einheitspartei Deutschlands (SED) z Berlina Zachodniego próbowali spacyfikować robotników. Zapobiegła temu zachodnioberlińska policja działająca $\mathrm{z}$ mandatu państw okupujących. AAPD 1980, dok. 279, Ministerialdirektor Blech, z. Z. New York, an das Auswärtige Amt, s. 1432, 1435, przypis 13.

7 Ibidem, dok. 282, Ministerialdirektor Blech, z. Z. New York, an das Auswärtige Amt, 24. September 1980, s. 1458.

8 Więcej o BND pisze A. Żebrowski, Polska Rzeczpospolita Ludowa w zainteresowaniu służb specjalnych wybranych państw, „Annales Universitatis Paedagogicae Cracoviensis. Studia Politologica” 13 (2014), s. 94-116.

9 AAPD 1980, dok. 256, s. 1342, przypis 8.

${ }^{10}$ Ibidem, dok. 279, s. 1435, przypis 13. W efekcie prośby dyplomacji RFN zgodzono się odstąpić od nakazu wyjazdu Rugego, ale w następnym roku przedłużono mu akredytację tylko o trzy miesiące. Harte Linie, „Der Spiegel” (29 XII 1980), nr 53, s. 14.

11 AAPD 1980, dok. 279, s. 1434, przypis 11.

12 Ibidem. 
W podobnie zaniepokojonym tonie wypowiadano się 24 października $1980 \mathrm{r}$. na naradzie resortowej w MSZ w Bonn. Wzięli w niej udział członkowie rządu, dyplomaci, wojskowi ze Sztabu Generalnego i pracownicy BND, a tematem była sytuacja w Polsce i groźba interwencji radzieckiej ${ }^{13}$. Bazując na informacjach BND, omówiono potencjał i możliwości operacyjne dostępnych rządowi PRL sił, przy czym wyrażano opinię, że raczej siły zewnętrzne byłyby aktywniejsze przy zdławieniu zamieszek. Z BND przekazano, że w ciągu 24 godzin mogło być gotowe do wymarszu i interwencji w Polsce do 10 dywizji radzieckich stacjonujących w NRD i 2 stacjonujące w Czechosłowacji. Dodatkowo do natychmiastowego wykorzystania w Polsce byłyby wojska NRD i kilka dywizji armii czechosłowackiej. W pierwszym rzędzie interweniować mogła armia radziecka, a w drugim rzucie - armie czechosłowacka i wschodnioniemiecka. Główne uderzenie radzieckie nadeszłoby ze strony $\mathrm{NRD}^{14}$.

Analizując potencjalne ruchy wojsk radzieckich stacjonujących w NRD, zwrócono uwagę na stanowisko obywateli Niemiec Wschodnich. Nie zakładano oporu czy sprzeciwu, bowiem ich stosunek do Polski był bardzo krytyczny ${ }^{15}$. Jak wynika z meldunków dyplomatów RFN, w olbrzymiej części społeczeństwa NRD występowało swoiste zadowolenie, że nareszcie „im pokażą” („Denen, mal gezeigt wird”), a także wysoki stopień arogancji wobec Polaków. Większość nie rozumiała, że w Polsce „rozgrywa się” również ich problem, jak pisał z Berlina sekretarz stanu RFN Günter Gaus ${ }^{16}$.

Uczestnicy narady byli pewni, że w rozważaniach na temat potencjalnej gotowości ZSRR do interwencji w Polsce należało wziąć pod uwagę radziecką ocenę Ludowego Wojska Polskiego (LWP). Ważne było ograniczone zaufanie dowódców radzieckich do polskich sił zbrojnych i ich posłuszeństwa ${ }^{17}$. Nie sądzono wprawdzie, aby Sztab Generalny LWP organizował opór przeciwko wojskom Układu Warszawskiego, ale dopuszczano wystąpienia przeciwko siłom interwencyjnym

13 Ibidem, dok. 300, Ressortbesprechung, 24. Oktober 1980, s. 1554-1560.

${ }^{14}$ Ibidem.

15 Nieco bardziej zróżnicowany stosunek obywateli NRD do wydarzeń w Polsce przedstawił biskup kościoła luterańskiego, dr Rathke, który twierdził, że w przypadku interwencji zbrojnej Niemiec Wschodnich w Polsce niektórzy obywatele NRD odmówiliby uczestnictwa w niej. AAPD 1982, dok. 229, Gespräch des Bundeskanzlers Schmidt mit dem Landesbischof der Evangelisch-Lutherischen Landeskirche Mecklenburgs, Rathke, am Brahmsee, 24. August 1982, s. 1217.

16 AAPD 1980, dok. 259, Staatssekretär Gaus, Ost-Berlin, an das Auswärtige Amt, 4. September 1980, s. $1352-1358$.

17 Ta opinia była bardzo zbliżona do tej, którą przekazało w listopadzie 1980 r. do Moskwy „kilku funkcjonariuszy PZPR wysokiego szczebla”, a także Kania na początku grudnia 1980 r. M. Kramer, Związek Radziecki, Układ Warszawski i polski kryzys w latach 1980-1981, w: Świat wobec „Solidarności”..., s. 28. O postawie LWP, a także gen. Wojciecha Jaruzelskiego zob. M. Świder, „Moskiewski pachołek” versus "polski patriota“. Niepubliczne opinie o generale Wojciechu Jaruzelskim z lat 1981-1982, w: O powinnościach żolnierskich, t. 3: Na krętych drogach żotnierskich losów, red. A. Drzewiecki, Oświęcim 2016, s. 186-207. 
części jednostek pod dowództwem niższych i średnich rangą oficerów. Oceniając aspiracje polityczne oficerów polskich, zauważono w Bonn, że nie występowały one w formie, która sugerowałaby chęć przejęcia władzy w kraju. Nie wykluczało to jednak możliwości czasowego objęcia określonych funkcji państwowych przez ich przedstawicieli ${ }^{18}$. (Motyw LWP powtarzał się kilkakrotnie m.in. w grudniu 1980 r. na nieformalnym spotkaniu czterech ministrów spraw zagranicznych: Genschera, Petera Alexandra Carringtona, Jeana François-Ponceta i Edmunda Muskiego. Wówczas dyskutowano o możliwej interwencji ZSRR w Polsce, bazując na ustaleniach wywiadu NATO, który podał, że Rosjanie brali pod uwagę możliwość zbrojnego wystąpienia armii polskiej przeciwko ich siłom. Oddziały LWP wzmocnione innymi uzbrojonymi służbami mogłyby stawiać opór przez $14 \mathrm{dni}^{19}$ ).

Prezydent BND Klaus Kinkel uznał na koniec dyskusji, że stan krytyczny $\mathrm{w}$ Polsce nie został jeszcze osiągnięty ${ }^{20}$. Ta konkluzja uwidoczniła się w opracowanych wówczas punktach, które miano brać pod uwagę przy określeniu strategii RFN wobec ZSRR i PRL:

1) w ZSRR nie wypracowano jeszcze koncepcji postępowania z PRL;

2) Moskwa powstrzyma się raczej od użycia siły;

3) możliwości interwencji nie są aż tak duże, jak się początkowo obawiano ${ }^{21}$;

4) nie ma możliwości nacisków gospodarczych na Związek Radziecki.

Poza tym ustalono, że ZSRR posiada punkt, którego przekroczenie wywoła najprawdopodobniej reperkusje w Moskwie. W zachowanej i udostępnionej badaczom dokumentacji brakuje jednak dokładniejszego określenia, czym był ten punkt według analizy BND, chociaż w prawie każdej relacji mowa jest o groźbie utraty przez PZPR kontroli nad krajem 22 .

O możliwych reakcjach ZSRR na wydarzenia w Polsce raportował pod koniec października 1980 r. ambasador RFN w Moskwie Andreas Meyer-Landrut. Jego zdaniem rząd radziecki chciał się mocniej i bezpośrednio zaangażować w sprawy polskie $^{23}$, co przypominało nieco sytuację z wiosny 1968 r. i późniejszą interwencję

18 AAPD 1980, dok. 300, s. 1556.

19 Ibidem, dok. 344, przypis 23.

20 Ibidem.

${ }^{21}$ Ten wniosek wyciągnięto $\mathrm{z}$ analizy sytuacji w LWP, możliwości i siły operacyjnej Milicji Obywatelskiej, a także postawy całego społeczeństwa polskiego.

${ }^{22}$ Najprawdopodobniej było blisko do przekroczenia tego krytycznego punktu, bowiem kanclerz Helmut Schmidt zwracał się kilkukrotnie (w październiku i listopadzie 1980) za pośrednictwem ambasadora RFN w Moskwie z osobistym posłaniem do Leonida Breżniewa, wskazując na niepokojący rozwój sytuacji wokół Polski. Zapewniając o restrykcyjnej wstrzemięźliwości w kontaktach w Polską, Schmidt rekomendował również innym sąsiadom Polski taką postawę. AAPD 1980, dok. 301, Vortragender Legationsrat I. Klasse Arnot an die Botschaft in Moskau, 24. Oktober 1980; ibidem, dok. 315, Botschafter Meyer-Landrut, Moskau, an das Auswärtige Amt, 6. November 1980.

${ }^{23}$ Ibidem, dok. 312, Botschafter Meyer-Landrut, Moskau, an das Auswärtige Amt, 31. Oktober 1980, s. 1612-1614. 
wojsk Układu Warszawskiego w Czechosłowacji. W tym kontekście wskazywano na szybką i wcześniej niezapowiedzianą wizytę w Moskwie I sekretarza Komitetu Centralnego (KC) PZPR Stanisława Kani i premiera PRL Józefa Pińkowskiego. Analiza zaistniałej sytuacji sprawiała trudności, dlatego posłużono się analogiami do 1968 r. Przede wszystkim wskazywane były podobieństwa tej wizyty do wezwania do Moskwy I sekretarza KC Komunistycznej Partii Czechosłowacji Alexandra Dubčeka w maju 1968 r. Jeżeli uzna się interwencje z lat 1956 i 1968 za modelowe, to - jak raportował Meyer-Landrut z Moskwy - ZSRR skłonny będzie do interwencji w Polsce w dwóch przypadkach: po pierwsze, PZPR zostanie pozbawiona możliwości obrony monopolu władzy; po drugie, monolityczna jedność partii będzie oddana na rzecz rzeczywistego pluralizmu politycznego. Poza tym rozwój sytuacji pozwalał na postawienie tezy, że Moskwa spróbuje w pierwszej kolejności wywierać naciski na Warszawę za pośrednictwem państw sąsiadujących, przede wszystkim NRD i Czechosłowacji2 ${ }^{24}$.

Tezę ambasadora Meyera-Landruta wzmacniać mogły słowa Andrieja Kirilenki, członka Biura Politycznego i członka Sekretariatu KC Komunistycznej Partii Związku Radzieckiego (KPZR), który przemawiając w Pilźnie, nie odniósł się wprawdzie bezpośrednio do sytuacji w Polsce, ale mówił o przeciwnikach klasowych, którzy próbują rozbić jedność braterską, wykorzystując przy tym występujące trudności przy budowie socjalizmu, i zniszczyć podstawy tego systemu społecznego ${ }^{25}$. Dla obserwatorów oznaczało to budowanie frontu przeciwko Warszawie i podjęcie wspólnej taktyki, a także konstruowanie tezy o mieszaniu się sił zachodnich w sprawy wewnętrzne Polski i bloku wschodniego. Te zarzuty można by rozwijać i w efekcie stworzyć odpowiedni klimat dla interwencji radzieckiej. Dla dyplomacji RFN oznaczać to mogło, że w Moskwie rozważano działania, które dla Zachodu nie będą zaskoczeniem. Niespodziany atak byłby znacznie trudniejszy do uzasadnienia niż interwencja w obronie Polski i interesów państw bloku wschodniego przed reakcjonizmem zachodnim. Analizowane w Bonn zachowania ZSRR w kontekście możliwego rozwiązania siłowego skutkowały opracowaniem dwóch tez: po pierwsze, ZSRR nie będzie zwracał uwagi na międzynarodowe koszty interwencji, po drugie, swoje działania uzasadni koniecznością obrony Polski przed mieszaniem się Zachodu w jej sprawy.

$\mathrm{O}$ działaniach zmierzających do zbudowania narracji ingerowania Zachodu w sytuację w PRL donosili dyplomaci niemieccy z Moskwy. Pod koniec października 1980 r. ambasador RFN ostrzegał: „Jeśli w Polsce nastąpi jakakolwiek interwencja radziecka, to będzie najprawdopodobniej uzasadniona koniecznością odpowiedzi na «ingerencję» Zachodu"26. Na niepokój Bonn wpływ miały również

24 Ibidem.

${ }^{25}$ Ibidem, s. 1613, przypis 9.

${ }^{26}$ Ibidem, dok. 312. Ta opinia pokrywała się ze stanowiskiem SED na temat roli RFN w wydarzeniach polskich. Joachim Hermann, członek Biura Politycznego SED zajmujący się propagandą i agitacją, mówił pod koniec października 1980 r. w Moskwie: „Kontrrewolucja nadal szturmuje. 
doniesienia prasowe i sposób relacji wydarzeń w Polsce przez wschodnioniemiecką prasę $e^{27}$. Od listopada 1980 r. propaganda NRD rozpoczęła ideologiczną ofensywę przeciwko Polsce, przypominającą komentarze z okresu przygotowania do interwencji w Czechosłowacji w 1968 r. ${ }^{28}$ Znaczny niepokój w RFN wywołały doniesienia o ruchach wojsk NRD w pasie przygranicznym $\mathrm{z}$ Polską. Było to nawet przedmiotem interpelacji poselskiej w Bundestagu, gdy jeden $\mathrm{z}$ posłów opozycji poprosił rząd o interpretację najnowszych wydarzeń na zachód od Odry. Chodziło o doniesienia o mobilizacji wschodnioniemieckich rezerwistów i wytyczenie obszaru zamkniętego o szerokości $50 \mathrm{~km}$ praktycznie wzdłuż całej granicy NRD-PRL, co nastąpiło 29 listopada 1980 r. Odpowiedź udzielona przez sekretarza stanu w Ministerstwie Obrony Wilfrieda Pennera potwierdzała te informacje. Przy okazji upubliczniono, że w jednostkach radzieckich stacjonujących w NRD podniesiono ich gotowość bojową ${ }^{29}$.

Każdy przejaw kooperacji Zachodu z Polską, bez względu na intencje i proweniencje (dziennikarze, koła gospodarcze, związki zawodowe czy nawet Kościoły) ${ }^{30}$, mógł być interpretowany jako dowód interwencji zachodniej. Mając to na uwadze i projektując możliwe scenariusze zdarzeń w Polsce i wokół naszego kraju, rozpoczęto w RFN szeroko zakrojone obserwacje rozwoju sytuacji w bloku wschodnim (prowadzone przez służby wywiadowcze), a także planowanie taktyki działania na wypadek zmiany stanu rzeczy, eskalacji napięć i interwencji radzieckiej w Polsce. Szczególnie w „małym kręgu” państw członkowskich NATO prowadzono tajne dyskusje o wypracowaniu wspólnej strategii wobec Polski i ZSRR.

BND sporządziła i przesłała na ręce szefa Urzędu Kanclerskiego szereg analiz, wskazujących na przygotowania do interwencji wojsk radzieckich w Polsce. Przykładowo pod koniec listopada 1980 r. w analizie stosunku Związku Radzieckiego do Polski BND zwróciła uwagę na przerzucenie żołnierzy radzieckich w drugim roku służby na tereny Polski i NRD. Ruchy te nie wynikały, jak należało przypuszczać, $\mathrm{z}$ rutynowych przemieszczeń. $\mathrm{W}$ analizie podkreślano dwie kwestie: stanowisko ZSRR

Naszym zdaniem sytuacja w Polsce jest gorsza niż w 1968 r. w Czechosłowacji, gorsza niż za czasów Dubceka” i dalej w kontekście roli RFN: „RFN była i jest centrum kontrrewolucyjnej ingerencji w Polsce Ludowej”, cyt. za: M. Wilke, Polityka interwencji SED. Prascy reformatorzy komunistyczni z 1968 roku i polski ruch demokratyczny z lat 1980-1981, „Pamięć i Sprawiedliwość" (2006), nr 1 (9), s. 63-91.

27 O reakcji prasy NRD na wydarzenia w Polsce zob. D. Wojtaszyn, Obraz Polski i Polaków w prasie i literaturze Niemieckiej Republiki Demokratycznej w okresie powstania Solidarności i stanu wojennego, Wrocław 2007.

28 F. Oldenburg, Das Verhältnis SED-PVAP während der Krise in Polen (Juli 1980 - Juli 1982), w: Polen 1982. Analysen der innenpolitischen Situation und der internationalen Auswirkungen, Köln 1982, s. 120.

29 Deutscher Bundestag, 9. Wahlperiode, 12. Sitzung, Drucksache 9/41, Donnerstag, den 18. Dezember 1980, s. 403D.

30 Solidarność związkowa. Niemiecka Federacja Związków Zawodowych (DGB) wobec NSZZ „Solidarność", wybór, wstęp i oprac. M. Świder, Kraków 2017. 
wobec działalności nowych związków zawodowych i opozycji w Polsce (ponoć nie było jednoznacznie wrogie), a także stanowisko NRD wobec wydarzeń nad Wisłą. Propagowana przez Berlin Wschodni teza o kontrrewolucji w Polsce i dążeniu Lecha Wałęsy do przejęcia władzy, a także zawieszenie bezpośrednich kontaktów partyjnych miały dowodzić powagi sytuacji i niepokoju w szeregach wschodnioniemieckich komunistów ${ }^{31}$. O zdenerwowaniu w Niemieckiej Socjalistycznej Partii Jedności (SED - Sozialistische Einheitspartei Deutschlands) świadczyć mogły też wprowadzone specjalne działania na wypadek zbrojnej interwencji Układu Warszawskiego w Polsce (niestety w analizie nie podano konkretnie, jakiego typu były to działania) ${ }^{32}$.

O możliwości interwencji mówiły również inne raporty BND z końca listopada i grudnia $1980 \mathrm{r}$. Analizując ruchy wojsk radzieckich, nietypową ciszę w eterze, a także wprowadzenie gotowości bojowej Armii Radzieckiej w Polsce i NRD, wywiad RFN był zdania, że do interwencji radzieckiej w Polsce może dojść w każdej chwili33. Tezę tę zdawali się potwierdzać dyplomaci radzieccy, którzy mówili o ostrzeżeniach Moskwy wobec Warszawy. W ostatnich dniach listopada $1980 \mathrm{r}$. BND przestrzegła, że w Polsce jest sytuacja „za pięć dwunasta”. Jeżeli wymknie się ona spod kontroli, to w każdej chwili Moskwa może zacząć działać34. W analizie BND z 28 listopada 1980 r. przytoczono wypowiedź Mieczysława Rakowskiego, który podczas polsko-niemieckiego spotkania w Loccum (21-23 listopada 1980 r.) miał skonsternowany stwierdzić, że w najbliższych dniach oczekuje ze strony Związku Radzieckiego fatalnych decyzji ${ }^{35}$. Analizy BND zawierały relacje również innych dyplomatów polskich, przebywających na Zachodzie (25 listopada 1980 r.), że oczekują decyzji o interwencji w najbliższym czasie. Podobnie mówili dyplomaci bułgarscy i rumuńscy. O zaplanowanej na 29-30 listopada $1980 \mathrm{r}$. interwencji mowa była w kręgach austriackiego ministra spraw zagranicznych, gdzie powoływano się na "wiarygodne informacje” 36 .

Decydujące znaczenie w ocenie sytuacji w Polsce pod kątem możliwej interwencji radzieckiej BND przypisywała VII Plenum KC PZPR (1-2 grudnia 1980 r.).

31 Bundesarchiv Koblenz (dalej: BAK), sygn. B 206/597, Infotec, An Chef Bundeskanzleramt, Betr.: Lage in Polen, 27. November 1980, k. 74-75.

32 Ibidem, Betr., DDR-Vorbereitungen für den Fall einer Intervention in Polen, 24. November 1980, k. 82-85.

33 Ibidem, An Chef Bundeskanzleramt, Betr.: Lage in und um Polen, hier: Fortschreibung Stand 1.12.1980, 0900 Uhr, Bezug: BND III B/III C. München, 30. November 1980, k. 63.

${ }^{34}$ Ibidem, Infotec, An Chef Bundeskanzleramt, Betr.: Lage in Polen, 30. November 1980, k. 54.

35 Ibidem, An Chef Bundeskanzleramt, Betr.: Lage in Polen, 28. November 1980, k. 64-65. Wypowiedź Rakowskiego znalazła się w analizie BND, a także w doniesieniach Stasi i dokumentach wewnętrznych Socjaldemokratycznej Partii Niemiec (SPD - Sozialdemokratische Partei Deutschlands). Obszerna notatka z rozmowy Eugena Selbmanna z Rakowskim i Ryszardem Wojną przeznaczona była dla kanclerza RFN. Potwierdzono w niej zagrożenie interwencją, a sytuację nazwano beznadziejną. Archiv der sozialen Demokratie (dalej: AdsD), Selbmann, sygn. 201, Eugen Selbmann, Herrn Bundeskanzler Helmut Schmidt, Bundeskanzleramt, 25.11.1980, persönlich.

${ }^{36}$ Ibidem, An Chef Bundeskanzleramt, Betr.: Lage in Polen, 28. November 1980, k. 64-65. 
Przedrukowanie w „Prawdzie” obszernego wystąpienia Kani było dla służb zachodnioniemieckich dowodem na spadek napięcia politycznego wokół Polski. Wydawało się, że kierunek polityczny naznaczony przez I sekretarza KC PZPR znalazł uznanie w oczach Kremla ${ }^{37}$. Natomiast w „Neues Deutschland” mowę Kani pominięto milczeniem, a obradom VII Plenum KC PZPR poświęcono niewiele miejsca ${ }^{38}$. Wkrótce jednak BND zauważyła niewielkie złagodzenie stanowiska NRD i Czechosłowacji, co mogło być efektem grudniowego spotkania na szczycie państw Układu Warszawskiego w Moskwie ${ }^{39}$ (5 grudnia 1980 r.) ${ }^{40}$. Wówczas Leonid Breżniew zdecydowanie sprzeciwił się postulatom NRD w sprawie interwencji w Polsce ${ }^{41}$. Tezę o łagodzącym stanowisku Breżniewa i „studzeniu” przez niego aspiracji wschodnioniemieckich potwierdzili politycy czechosłowaccy w rozmowie z Genscherem pod koniec grudnia $1980 \mathrm{r}^{42}$, o czym mowa będzie dalej.

Ważną rolę w kształtowaniu opinii na temat możliwości interwencji radzieckiej w Polsce odgrywały konsultacje państw członków NATO w sprawie Polski. Wśród nich strategiczne miejsce zajmowały narady odbywane w ramach struktur NATO, ale w organicznym kręgu osób. Przykładem takich narad może być wspomniane już wcześniej nieformalne spotkanie ministrów spraw zagranicznych czterech państw członków NATO. Na wniosek USA zwołano 2 grudnia 1980 r. posiedzenie Rady NATO w tzw. najmniejszym kręgu ${ }^{43}$. Głównym celem nieformalnego spotkania (private meeting) było określenie ewentualnego planu działania na wypadek interwencji radzieckiej w Polsce. Mimo że praktycznie wszyscy uczestnicy tej rundy rozmów potwierdzali możliwe zagrożenie interwencją, wskazując na ruchy wojsk ZSRR, NRD i Czechosłowacji, nie zdołano wówczas zaproponować konkretnych rozwiązań. Ambasador RFN przy NATO Hans-Georg Wieck podkreślał konieczność ustalenia zakresu działań NATO, szczególnie w sferze sygnałów politycznych, zanim jeszcze dojdzie do interwencji. Ponadto należało zastanowić się nad ewentualnymi skutkami inicjatyw podejmowanych przez NATO i jej członków. Pytanie brzmiało, czy nie były one same w sobie powodem zwiększonej niepewności ZSRR i wzrostu gotowości Moskwy do interwencji? ${ }^{44}$ Nie wiedziano przecież,

37 Ibidem, Infotec, An Chef Bundeskanzleramt, Betr.: Lage in Polen, 3. Dezember 1980, k. 48-49.

38 Ibidem, Infotec, An Chef Bundeskanzleramt, Betr.: Lage in Polen, 4. Dezember 1980, k. 45.

39 Więcej na ten temat zob. Stenogram ze spotkania przywódców państw członkowskich Układu Warszawskiego, 5.12.1980, w: Przed i po 13 grudnia..., s. 234-280.

40 BAK, sygn. B 206/597, Infotec, An Chef Bundeskanzleramt, Betr.: Lage in Polen, 5. Dezember 1980, k. 35 .

${ }^{41}$ F. Oldenburg, op. cit., s. 120. Rozluźnienie atmosfery zauważone zostało w Polsce. Również Kościół, a przede wszystkim prymas Wyszyński tak właśnie odczytał zmianę nastrojów wokół Polski. Zob. R. Łatka, op. cit.

42 AAPD 1980, dok. 373, Ministerialdirektor Blech an Botschafter Hermes, Washington, Gesandten Mühlen, Paris und Botschafter Ruhfus, London, 22. Dezember 1980, s. 1928-1934.

43 Ibidem, dok. 344, Botschafter Wieck, Brüssel (NATO), an das Auswärtige Amt, 2. Dezember 1980, s. 1784-1789.

${ }^{44}$ Ibidem, przypis 1, 22. 
które z nich stanowiły dla ZSRR prowokację, a które mogły odstraszać. Jedyną kwestią, co do której panowała zgodność wśród państw uczestniczących w private meeting, była potrzeba opracowania planu działania na wypadek interwencji radzieckiej w PRL - Eventualfallplanung. Istniała również zgoda co do tego, że rozmowy należało prowadzić przy zachowaniu najwyższej ostrożności i tajemnicy. Dyskrecja była konieczna, ponieważ wypracowane plany NATO na ewentualność interwencji ZSRR w PRL mogły posłużyć Związkowi Radzieckiemu jako doskonały pretekst do interwencji. Jak pisał we wrześniu Meyer-Landrut, gdyby miało do niej dość, to zapewne zostałaby ona przedstawiona jako reakcja na mieszanie się Zachodu w sprawy Polski ${ }^{45}$.

Opinie i obawy o reakcję ZSRR, prezentowane na forum NATO, wzmacniane były sugestiami, jakie przychodziły do najbliższych współpracowników kanclerza RFN za pośrednictwem tajnego kanału dyplomatycznego Bonn-Moskwa (Back channel), funkcjonującego poza strukturami politycznymi czy wywiadowczymi $^{46}$. Powstał on w 1969 r. z inicjatywy szefa KGB Jurija Andropowa (dopiero w 1982 r. strona niemiecka dowiedziała się, kto „stał na końcu” tego kanału). Wysłannikiem Kremla był Walerij Lednew, Bonn reprezentował Egon Bahr. Na spotkaniach mówiono o ważnych kwestiach, np. o planowanej interwencji ZSRR w Afganistanie. W 1980 r. za pośrednictwem Back channel poinformowano Bonn, że powszechne oczekiwanie na interwencję radziecką w Polsce i snucie hipotez na ten temat oceniane są w Moskwie bardzo negatywnie. Jak zapewniano, podczas dwóch pierwszych miesięcy wydarzeń na Wybrzeżu ZSRR nie widział powodów do niepokoju czy potrzeby radykalnych działań. Jedyną kwestią, która musiała martwić, była postawa „pewnych” sił na Zachodzie, chcących wpłynąć na rozwój sytuacji w Polsce. ZSRR traktował wydarzenia z życzliwością, a nawet jako przydatne doświadczenie dla pozostałych państw socjalistycznych. Opinie przekazane za pośrednictwem kanału mogły odpowiadać nastrojom w Moskwie, bowiem Andropow, który stał na końcu Back channel, był również członkiem powołanej 25 sierpnia 1980 r. przez Biuro Polityczne KPZR specjalnej Komisji ds. Polski (tzw. komisja Susłowa) ${ }^{47}$.

Mimo podejmowanych przez ZSRR prób zniechęcenia Zachodu do rozmów na temat strategii działania Moskwy wobec Warszawy, temat interwencji, jej daty czy też ewentualnego zagrożenia dla państw NATO ze strony Związku Radzieckiego omawiano na spotkaniach Paktu Północnoatlantyckiego. Najważniejsze rozmowy prowadzone były w tzw. małym kręgu. 10 grudnia 1980 r., czyli dzień przed rozpoczęciem jesiennej tury obrad Rady Ministrów NATO spotkali się ministrowie

45 Ibidem, dok. 312, Botschafter Meyer-Landrut, Moskau, an das Auswärtige Amt, 31. Oktober 1980, s. 1612-1614.

46 V.E. Kevorkov, Der geheime Kanal. Moskau, der KGB und die Ostpolitik. Mit einem Nachwort von Egon Bahr, Berlin 1995, s. 272-273; K. Wiegrefe, Das Zerwürfnis. Helmut Schmidt, Jimmy Carter und die Krise der deutsch-amerikanischen Beziehungen, Berlin 2005, s. 284.

${ }^{47}$ M. Kramer, op. cit., s. 27. 
spraw zagranicznych: Francji, Wielkiej Brytanii, RFN i USA ${ }^{48}$. Minister Genscher zaproponowal, aby zastanowić nad trzema punktami:

1) wymianą informacji i interpretacji strategii działania ZSRR;

2) pytaniem o ewentualną koncentrację Zachodu na kwestii zapobieżenia eskalacji napięcia (dotychczasowe dyskusje mogły sugerować, że Zachód wkalkulował w bieżącą politykę interwencję radziecką i zajmował się jedynie dyskusją nad reakcją na to oczekiwane wydarzenie);

3) kwestią określenia tego, co należy uznać za interwencję ${ }^{49}$.

Ostatni punkt miał duże znaczenie, zważywszy na fakt, że na 16 grudnia 1980 r. zaplanowano manewry Układu Warszawskiego, które mogły stanowić pretekst do wprowadzenia obcych wojsk do Polski. Zresztą był to jeden z problemów, z którymi musiano zmierzyć się na arenie międzynarodowej. Przykładowo kanclerz Helmut Schmidt w grudniowej rozmowie z premierem Włoch mówił w kontekście interwencji ZSRR w Polsce o „przeciekającym wkroczeniu” (sickernder Einmarsch), a minister obrony USA Caspar Weinberger - o interwencji przez osmozę $^{50}$. Minister spraw zagranicznych Wielkiej Brytanii Lord Carrington był przekonany, że ZSRR zdaje sobie sprawę z międzynarodowych konsekwencji interwencji, nawet jeżeli nie wie o szczegółach ustaleń. Uważał również, że zdecydują się na nią tylko wtedy, gdy jej cena będzie niższa niż rezygnacja z zaangażowania w Polsce. Podobną opinię prezentował francuski minister spraw zagranicznych. Wypracowanie porozumienia, tak aby nie pozwolić na powstanie wrażenia braku jedności czy wręcz różnicy zdań wśród państw NATO, stało się priorytetem. Równie ważne było doprecyzowanie, co należy uznać za interwencję, którą Genscher nazwał w trakcie dyskusji „śmiertelnym ciosem dla odprężenia”. Ministrowie zgodzili się, że klasyczna jej forma (jak w 1956 r. na Węgrzech i 1968 r. w Czechosłowacji) będzie ostatnim elementem branym pod uwagę przez ZSRR. Równocześnie ministrowie zdecydowali, że w oświadczeniu Rady NATO znajdzie się stwierdzenie, że ewentualna interwencja w Polsce zmieni sytuację międzynarodową, a państwa Paktu zostały przygotowane do adekwatnej reak$\mathrm{cji}^{51}$. Istotnie w punkcie 1 komunikatu końcowego $\mathrm{z} 12$ grudnia $1980 \mathrm{r}$. mowa jest o Polsce ${ }^{52}$. Poza tym - jak wynika z opublikowanych materiałów - po wysłuchaniu uwag dowództwa wojsk NATO liczono się z interwencją ZSRR w Polsce

48 AAPD 1980, dok. 357, Gespräch des Bundesministers Genscher mit dem britischen Außenminister Lord Carrington, dem französischen Außenminister François-Poncet und dem amerikanischen Außenminister Muskie in Brüssel, s. 1843-1853.

49 Ibidem.

50 Ibidem, dok. 358, Aufzeichnung Ministerialdirektors von Staden, Bundeskanzleramt, 10. Dezember 1980, s. 1855-1860; Akten zur Auswärtigen Politik der Bundesrepublik Deutschland 1981 (dalej: AAPD 1981), München 2012, dok. 103, Aufzeichnung Vortragenden Legationsrats I. Klasse Hofmann, 7. April 1981, s. 560-563.

51 AAPD 1980, dok. 357.

52 Archiwum Akt Nowych, Komitet Centralny PZPR, sygn. XI A/1273, Ministerstwo Spraw Zagranicznych, Szyfrogram nr 3488/IV z Brukseli, 16.12.1980, tajne, k. 163. 
dopiero po 15 grudnia, co miało związek z przymrozkami, które mogły umożliwić szersze użycie czołgów ${ }^{53}$.

Dyskusja prowadzona w „małym kręgu” okazała się bardzo dobrą metodą dochodzenia do konsensusu. Ministrowie uważali, że takie obrady (ministrowie i stali przedstawiciele) są najbardziej produktywne i należy tę ich formę kontynuowaćs ${ }^{54}$. Następne spotkanie planowano na początek marca 1981 r. w Brukseli, lecz doszło do niego dopiero w maju w Rzymie, niemniej jednak dało to początek całej serii spotkań, na których omawiano sytuację w Polsce. Ich intensyfikacja miała miejsce w 1981 r., przy czym szczególnie często spotykano się po wprowadzeniu stanu wojennego w Polsce.

Grudniowe spotkanie w „małym kręgu” dało również impuls do intensyfikacji prac dyrektorów departamentów politycznych i departamentów ekonomicznych z MSZ czterech najważniejszych państw NATO ${ }^{55}$. Było to forum merytorycznych konsultacji, a w ich trakcie dyskutowano nad pozycjami poszczególnych państw, wypracowując wspólne stanowiska. Zgodnie z mandatem udzielonym przez uczestników „małego kręgu” 10 grudnia 1980 r. rozpoczęły się prace dyrektorów nad problematyką polską, o czym donosił z Brukseli Ministerialdirektor Blech. 15 grudnia $1980 \mathrm{r}$. w Londynie, w trakcie takiego posiedzenia, wypracowano wstępny katalog środków możliwych do zastosowania wobec ZSRR i bloku wschodniego na wypadek interwencji w Polsce (contingency planning - Planung für Eventuallfälle). Było to pierwsze spotkanie dyrektorów departamentów w cyklu poświęcone sytuacji w Polsce ${ }^{56}$, a w jego trakcie opracowano podstawowe założenia katalogu możliwych działań politycznych ${ }^{57}$ i gospodarczych, stanowiących potencjalną odpowiedź Zachodu na interwencję $e^{58}$.

Niezmiernie ważne informacje potwierdzające powagę sytuacji, a także trafność większości ustaleń, jakich dokonano w RFN i w trakcie spotkań w „małym kręgu” państw NATO, pozyskano w Pradze podczas wizyty Genschera (18-20 grudnia 1980 r. ${ }^{59}$. Problem polski stał na pierwszym miejscu pod względem zarówno ważkości, jak i długości rozmów ministra spraw zagranicznych RFN z partnerami czechosłowackimi. Zgodnie z notatką Genscher omawiał polski temat podczas 4,5-godzinnej rozmowy w cztery oczy z Bohuslavem Chňoupkiem 18 grudnia, 1,5-godzinnej rozmowy z Lubomírem Štrougalem 19 grudnia, 1,5-godzinnej rozmowy z Gustávem

53 AAPD 1980, dok. 344, przypis 23.

54 Ibidem, dok. 363, Botschafter Wieck, Brüssel (NATO), an das Auswärtige Amt, s. 1879-1881.

55 AAPD 1981, dok. 125, Gespräch des Bundesministers Genscher mit den Außenminister Lord Carrington (Großbritannien), François-Poncet (Frankreich) und Haig (USA) in Rom, 3. Mai 1981, s. 694-707.

56 Dyrektorzy wydziałów politycznych i ekonomicznych w MSZ czterech państw NATO spotykali się regularnie, ale dopiero od jesieni 1980 r. ich spotkania poświęcone były kwestiom polskim.

57 AAPD 1980, dok. 366, Aufzeichnung des Ministerialdirektors Blech, 16. Dezember 1980, s. 18901899.

58 Ibidem, dok. 367, Aufzeichnung des Ministerialdirektors Fischer, s. 1899-1904.

59 Ibidem, dok. 373. 
Husákiem również 19 grudnia $1980 \mathrm{r}$. i wieczornej rozmowy w cztery oczy ze Štrougalem, odbytej 19 grudnia w ambasadzie RFN. Genscher przedstawił stanowisko państw Europejskiej Wspólnoty Gospodarczej (EWG; oświadczenie luksemburskie z 2 grudnia ${ }^{60}$ ) i NATO (komunikat Rady Ministerialnej NATO z 12 grudnia), a także wyartykułował determinację państw Zachodu i ich obawy związane z potencjalną interwencją ZSRR w Polsce. Jak wynika $\mathrm{z}$ relacji z tych rozmów, politycy czechosłowaccy nie krytykowali dokumentów EWG czy NATO, ale postawę mediów zachodnich, które dramatyzowały i straszyły, tworząc atmosferę histerii. Generalnie rzecz ujmując, rozmówcy Genschera starali się rozwiać obawy Zachodu. Równocześnie przyznano, że na grudniowym szczycie w Moskwie mowa była o Polsce. Delegacja z Warszawy miała zapewnić, że PRL pozostanie państwem socjalistycznym, które będzie wypełniało swoje zobowiązania wynikające z członkostwa w Układzie Warszawskim i Radzie Wzajemnej Pomocy Gospodarczej ${ }^{61}$.

Znacznie więcej na temat spotkania moskiewskiego przekazał Genscherowi podczas wieczornej rozmowy w cztery oczy premier Czechosłowacji Štrougal. Z jego relacji wynikało, że wbrew wrażeniu władze poszczególnych państw socjalistycznych nie były jednolite w swoich poglądach (dotyczyło to również przekonań towarzyszy czechosłowackich). Na „szczycie” moskiewskim w swojej polemice i ostrości wypowiedzi w kwestiach polskich wyróżniała się delegacja NRD, która opowiadała się za interwencją ${ }^{62}$. Sprzeciwiali się temu Węgrzy, Rumunii i Bułgarzy. W związku z wystąpieniami delegacji NRD Breżniew musiał interweniować stwierdzeniem, że „Polacy są po prostu Polakami i czołgami nie można u nich niczego zdziałać”33.

Informacje Štrougala przekazane Genscherowi przeznaczone były tylko dla najwyższych władz RFN i najbliższych sojuszników. O zachowanie tajemnicy poprosił premier, dopuszczając jednocześnie ich rozdysponowanie odpowiednim osobom

${ }^{60} \mathrm{Na} 18$ posiedzeniu Rady Europejskiej w Luksemburgu (1-2 grudnia 1980 r.) podkreślono solidarność z narodem polskim, a także nadzieję na rozwiązanie kryzysu zgodnie z Kartą ONZ i Aktem końcowym KBWE. W oświadczeniu nie wymieniono jednak ZSRR w kontekście zagrożenia Polski. „Bulletin der EG” 12 (1980), s. 11 i n., http://www.youscribe.com/catalogue/rapportset-theses/ressourcesprofessionnelles/droit-et-juridique/bulletm-der-europaischen-gemeinschaftennr-12-1980-13-jahrgang-1158212 (dostęp: 1.02.2020).

61 AAPD 1980, dok. 373.

62 O stanowisku NRD wobec sytuacji w Polsce pisze Manfred Wilke: „Już pod koniec września 1980 r. Biuro Polityczne SED przegłosowało propozycję Honeckera, ażeby «zwrócić się do towarzysza Breżniewa z propozycją przeprowadzenia narady sekretarzy generalnych względnie I sekretarzy bratnich partii krajów socjalistycznych dotyczącej aktualnych spraw politycznych». Było to żądanie ustalenia oficjalnego mechanizmu konsultacyjnego w ramach bloku wschodniego według wzoru czechosłowackiego z 1968 r.; chodziło o to, by «kolektywnie» decydować o sprawach polskich", M. Wilke, op. cit., s. 79. Zob. też: Przed i po 13 grudnia..., passim.

63 O podobnej rozmowie z 5 grudnia 1980 r. (Kania-Breżniew) pisze Jerzy Eisler, cytując słowa Kani, że w wypadku interwencji wojsk Układu Warszawskiego „[...] pójdą na czołgi młodzi chłopcy, jak w Powstaniu Warszawskim, z butelkami benzyny, popłynie morze krwi. [...] wrażliwość Polaków na suwerenność, na gwałcenie niepodległości nie ma równej w Europie”, J. Eisler, „Polskie miesiace”, czyli kryzys(y) w PRL, Warszawa 2008, s. 207-208. 
z zachowaniem właściwych środków ostrożności. Istotnie minister spraw zagranicznych RFN podzielił się wiedzą zdobytą w Pradze z pozostałymi członkami „małego kręgu”. Przy okazji interpretowano działania podjęte przez Štrougala jako próbę uspokojenia Zachodu. Dla bońskiej dyplomacji znaczenie miało uzyskane z Pragi potwierdzenie szczególnego zaangażowania NRD w kwestię ewentualnej interwencji bloku w Polsce. Zdaniem Genschera to Berlin Wschodni był głównym krytykiem działań rządu PRL ${ }^{64}$. Nie mniej ważna okazała się pewność, że kwestia interwencji wojsk Układu Warszawskiego stanowi poważny przedmiot rozmów, a nawet przygotowań $\mathrm{w}$ stolicach bloku wschodniego. W tym czasie w gronie tzw. małego kręgu NATO rozpoczęto ściśle tajne prace nad scenariuszem reakcji NATO na wypadek interwencji radzieckiej czy innych zdarzeń wojennych w Polsce (Eventualfallplan), o czym mowa była już wcześniej ${ }^{65}$. Wypracowane plany znalazły w większości zastosowanie po wprowadzeniu 13 grudnia 1981 r. stanu wojennego.

Analizując zachowane i dostępne dokumenty źródłowe, należy podkreślić, że od pierwszych niepokoi w Polsce państwa zachodnie liczyły się z możliwością siłowego zdyscyplinowania Polaków, zgodnie z dotychczasową radziecką praktyką pacyfikowania niepokornych społeczeństw (Berlin 1953, Budapeszt 1956 czy Praga 1968). Rozwój sytuacji oceniano jako bardzo dynamiczny i animujący do podejmowania zdecydowanych działań, przy tym wskazywano w Bonn na pewne podobieństwa sytuacji w Polsce do sytuacji w Pradze z okresu poprzedzającego interwencję Układu Warszawskiego. Liczono się z zaangażowaniem wojsk nie tylko radzieckich, lecz także wschodnioniemieckich i czechosłowackich. Najprawdopodobniej impuls, który mógłby wyzwolić działania zbrojne, stanowiły oddanie monopolu władzy przez PZPR lub decyzja o prawdziwym pluralizmie politycznym. Dyplomaci zachodnioniemieccy wskazywali, że dla procesu decyzyjnego ZSRR nie bez znaczenia była postawa zarówno społeczeństwa, $z$ natury antyradzieckiego, jak i LWP. To właśnie ten element podnoszono często w dyskusjach i analizach prowadzonych na Zachodzie. Przy czym wskazywano na możliwość powstania w Polsce totalnego frontu, który, jak podkreślano w Bonn i na arenie międzynarodowej, był

${ }^{64}$ Informacje z Pragi potwierdzały ocenę dokonaną przez służby wywiadowcze RFN. Przykładowo w dokumentacji przygotowanej 27 listopada 1980 r. na tzw. Grosse Lagebesprechung (odprawa w tzw. dużym kręgu w Urzędzie Kanclerskim) mowa była o „mocnych” wyzwiskach, jakie kierowali pod adresem działaczy Solidarności i Lecha Wałęsy towarzysze z SED, a także o znacznie mniej dosadnych określeniach, jak skłonności faszystowskie, wroga postawa wobec odprężenia czy antyradzieckość. W efekcie wstrzymano wszelkie oficjalne kontakty partyjne, a wyjątki były dopuszczalne jedynie za osobistą zgodą Ericha Honeckera. Dla decydentów RFN ważniejsze były jednak informacje o widocznej dyskrepancji stanowiska NRD i ZSRR wobec wydarzeń w Polsce. Na pierwszy rzut oka stanowisko NRD dalece różniło się od stanowiska ZSRR. W tej sytuacji stawiano sobie pytania: czy ZSRR i NRD odgrywają z góry ustalone role? Czy NRD musiało wziąć na siebie rolę Scharfmachers (podżegacza)? A może towarzysze z Berlina Wschodniego posiadali na tyle duże możliwości, że zdecydowali się na nieco samodzielności? BAK, sygn. B 206/596, DDR-Blockpolitik, k. 78-79.

${ }^{65}$ Więcej na ten temat zob. M. Świder, op. cit., s. 174 i n. 
jednym $z$ elementów powstrzymujących radzieckie plany inwazyjne. Ta teza znalazła potwierdzenie w opiniach wygłoszonych w Pradze.

Na pewno na zachowania Zachodu wpływ miały sygnały wysyłane z Moskwy. Deklarowana przez RFN i inne państwa powściągliwość w sprawach Polski była nakazem chwili, a dotyczyło to zarówno działań rządów i partii politycznych, jak i dziennikarzy, związkowców oraz organizacji pozarządowych ${ }^{66}$. W analizach przygotowywanych dla i przez dyplomatów zachodnich uderza ich trafność oceny, a także wielość kanałów informacyjnych, co widać z perspektywy czasu i konfrontacji ze źródłami różnej proweniencji.

\section{West German Diplomacy on the Threat of Soviet Military Intervention in Poland - Autumn 1980}

\section{Abstract}

Based on German archival materials, above all from the Political Archive of the Federal Foreign Office in Bonn and declassified materials of the Federal Intelligence Service, an attempt was made to answer three fundamental questions: Did the German government reckon with the USSR's intervention in Poland? What conditions had to be met for the USSR to decide on armed intervention in Poland? Did the situation in Poland show similarities to the situation in Czechoslovakia in 1968? The analysis showed that from the first days of the unrest in Poland, Western countries considered the possibility of disciplining the Polish nation by force, according to the previous Soviet practice of pacifying rebellious people (Berlin 1953, Budapest 1956, or Prague 1968). The situation was assessed as very dynamic and encouraging to take decisive actions. The Polish reality showed certain similarities to the situation in Prague in the period preceding the Warsaw Pact interventions. In Germany, it was expected that both Soviet, East German, and Czechoslovakian troops might be involved in the intervention in Poland. A potential impulse triggering military action by Moscow could have been the threat of giving up the monopoly of power by the Polish United Workers' Party or a decision on a genuine political pluralism in the Polish People's Republic.

After December 1980, top-secret work began in the so-called small NATO group on a scenario for the North American Pact's reaction to a Soviet intervention or other war events in Poland (Eventualfallplan). These plans were primarily applied after the introduction of martial law in Poland on 13 December 1981.

\section{Западногерманская дипломатия об угрозе советской военной интервенции в Польше - осень 1980 г.}

\section{Аннотация}

На основе немецких архивных материалов, прежде всего из боннского Политического архива Министерства иностранных дел и рассекреченных материалов Федеральной разведывательной службы, была предпринята попытка ответить на три фундаментальных

${ }^{66}$ O polsko-zachodnioniemieckich stosunkach związkowych zob. Solidarność związkowa..., passim. 
вопроса: учитывало ли западногерманское правительство возможность советской интервенции в Польше? Какие условия должны были быть выполнены, чтобы СССР решился на силовые действия? Обнаруживалось ли сходство ситуации в Польше с ситуацией в Чехословакии в 1968 году? Анализ показал, что с первых дней волнений в Польше западные страны учитывали возможность дисциплинировать поляков силой, в соответствии с предыдущей советской практикой усмирения мятежных обществ (Берлин 1953, Будапешт 1956 или Прага 1968). Развитие ситуации было оценено как очень динамичное и побуждающее к решительным действиям. В польской действительности обнаруживалось определенное сходство с ситуацией в Праге в период, предшествовавший интервенции Варшавского договора. В ФРГ ожидалось, что в интервенции в Польшу могут быть задействованы как советские, так и восточногерманские и чехословацкие войска. Потенциальным импульсом, вызывающим военные действия Москвы, могла стать угроза отказа ПОРП от монополии на власть или решение ввести настоящий политический плюрализм в ПНР.

После декабрьского кризиса 1980 года в т.н. узком кругу НАТО началась сверхсекретная работа над сценарием реакции Североатлантического пакта в случае советской интервенции или других военных событий в Польше (Eventualfallplan). Эти планы в большинстве нашли применение после введения 13 декабря 1981 г военного положения в Польше.

\section{Bibliografia}

\section{Źródła archiwalne}

Archiv der sozialen Demokratie (Archiwum Socjaldemokracji Niemieckiej w Bonn) Depositum Selbmann

Archiwum Akt Nowych w Warszawie Komitet Centralny PZPR

Bundesarchiv Koblenz (Archiwum Federalne w Koblencji) Bundesnachrichtendienst

\section{Źródła drukowane}

Akten zur Auswärtigen Politik der Bundesrepublik Deutschland 1980, Bd. 1: Januar bis 30. Juni 1980, Bd. 2: 1. Juli bis 31. Dezember 1980, München 2011.

Akten zur Auswärtigen Politik der Bundesrepublik Deutschland 1981, Bd. 1: Januar bis 30. April 1981, Bd. 2: 1. Mai bis 30. September 1981, Bd. 3: 1. Oktober bis 31. Dezember 1981, München 2012.

Deutscher Bundestag, 9. Wahlperiode, 12. Sitzung, Drucksache 9/41, Donnerstag, den 18. Dezember 1980.

Przed i po 13 grudnia. Państwa bloku wschodniego wobec kryzysu w PRL 1980-1982, t. 1: Sierpień 1980 - marzec 1981, wybór, wstęp i oprac. Ł. Kamiński, Warszawa 2006.

\section{Opracowania}

„Bulletin der EG” 12 (1980), http://www.youscribe.com/catalogue/rapports-et-theses/ressourcesprofessionnelles/droit-et-juridique/bulletm-der-europaischen-gemeinschaften-nr-12-198013-jahrgang-1158212 (dostęp: 1.02.2020). 
Eisler J., „Polskie miesiace”, czyli kryzys(y) w PRL, Warszawa 2008.

Harte Linie, „Der Spiegel” 53 (29 XII 1980), s. 13-15.

Jaruzelski W., Różnić się mądrze. Jak doszło do stanu wojennego, Warszawa 2000.

Kemp-Welch A., Sowieckie reakcje na NSZZ „Solidarność” w latach 1980-1989, w: Świat wobec „Solidarności” 1980-1989, red. P. Jaworski, Ł. Kamiński, Warszawa 2013, s. 63-84.

Kramer M., Związek Radziecki, Układ Warszawski i polski kryzys w latach 1980-1981, w: Świat wobec „Solidarności” 1980-1989, red. P. Jaworski, Ł. Kamiński, Warszawa 2013, s. 24-62.

Kevorkov V.E., Der geheime Kanal. Moskau, der KGB und die Ostpolitik. Mit einem Nachwort von Egon Bahr, Berlin 1995.

Łatka R., Prymas Stefan Wyszyński wobec zagrożenia interwencja sowiecka i konsekwencje jego pogląów (1980-1981), „Studia z Dziejów Rosji i Europy Środkowo-Wschodniej” 53 (2018), z. 1, s. 145-164.

Oldenburg, F., Das Verhältnis SED-PVAP während der Krise in Polen (Juli 1980 - Juli 1982), w: Polen 1982. Analysen der innenpolitischen Situation und der internationalen Auswirkungen, Köln 1982, s. 112-136.

Paczkowski, A., Droga do „mniejszego zła”. Strategia i taktyka obozu władzy lipiec 1980 - styczeń 1982, Kraków 2002.

Paczkowski A., Moskwa a „kryzys polski” 1980-1982, w: Białe plamy - czarne plamy. Sprawy trudne $w$ relacjach polsko-rosyjskich (1918-2008), red. A.D. Rotfeld, A.W. Torkunow, Warszawa 2010, s. 715-728.

Solidarność związkowa. Niemiecka Federacja Związków Zawodowych (DGB) wobec NSZZ „Solidarność", wybór, wstęp i oprac. M. Świder, Kraków 2017.

Świder M., „Moskiewski pachołek” versus „polski patriota”. Niepubliczne opinie o generale Wojciechu Jaruzelskim z lat 1981-1982, w: O powinnościach żołnierskich, t. 3: Na krętych drogach żołnierskich losów, red. A. Drzewiecki, Oświęcim 2016, s. 186-207.

Świder M., Stanowisko Socjaldemokratycznej Partii Niemiec wobec Polski w latach 1980-1989, Opole 2015.

Wiegrefe K., Das Zerwürfnis. Helmut Schmidt, Jimmy Carter und die Krise der deutsch-amerikanischen Beziehungen, Berlin 2005.

Wilke M., Polityka interwencji SED. Prascy reformatorzy komunistyczni z 1968 roku i polski ruch demokratyczny z lat 1980-1981, „Pamięć i Sprawiedliwość” (2006), nr 1 (9), s. 63-91.

Wojtaszyn D., Obraz Polski i Polaków w prasie i literaturze Niemieckiej Republiki Demokratycznej w okresie powstania Solidarności i stanu wojennego, Wrocław 2007.

Żebrowski A., Polska Rzeczpospolita Ludowa w zainteresowaniu służb specjalnych wybranych państw, „Annales Universitatis Paedagogicae Cracoviensis. Studia Politologica” 13 (2014), s. 94-116.

Żukowski, M., Stan wojenny. Analizy, hipotezy, komentarze, Koszalin 2012.

Małgorzata Świder, dr hab. nauk humanistycznych w zakresie historii, prof. Uniwersytetu Pedagogicznego im. KEN w Krakowie. Zainteresowania naukowe: stosunki polsko-niemieckie w okresie powojennym, socjaldemokracja niemiecka, polsko-niemieckie relacje związkowe i dzieje najnowsze Śląska (malgorzata.swider@up.krakow.pl).

Małgorzata Świder, PhD with habilitation in history, Professor at the Pedagogical University of Cracow. Her scientific interests focus on the Polish-German relations in the post-war period, German Social Democracy, Polish-German trade union relations, and the recent history of Silesia (malgorzata.swider@up.krakow.pl). 